\title{
Voltage-Gated Sodium Channel Expression in Rat Spiral
}

\section{Ganglion Neurons}

\author{
Fryatt A.G ${ }^{1}$, Vial $C^{1}$, Mulheran $M^{1}$, Gunthorpe M.J. ${ }^{2}$, Grubb B.D ${ }^{1}$ \\ ${ }^{1}$ Department of Cell Physiology and Pharmacology, University of Leicester, University Road, \\ Leicester, United Kingdom LE1 9HN \\ ${ }^{2}$ Neurosciences Centre of Excellence for Drug Discovery, GlaxoSmithKline Research \& \\ Development, New Frontiers Science Park, Harlow, Essex, United Kingdom. CM19 5AW
}

Correspondence: agf4@le.ac.uk, AG Fryatt, address as above 


\begin{abstract}
The spiral ganglion neurons (SGN) provide the afferent innervation of the hair cells in the organ or Corti and relay auditory information from the inner ear to the brain. Voltage-gated sodium channels $(\mathrm{Nav})$ initiate and propagate action potentials that encode this sensory information but little is known regarding the subtypes expressed in these cells. We have used RT-PCR and immunohistochemistry to study the compliment and anatomical distribution of $\mathrm{Na}_{\mathrm{V}}$ channels in rodent SGN. $\mathrm{Na}_{\mathrm{V}} 1.1, \mathrm{Na}_{\mathrm{V}} 1.6$ and $\mathrm{Na}_{\mathrm{V}} 1.7$ were all detected at the mRNA level. Fluorescence or streptavidin-horseradish peroxidase immunohistochemistry extended these findings, demonstrating predominant localisation of $\mathrm{Na}_{\vee} 1.6$ and $\mathrm{Na}_{\mathrm{V}} 1.7$ on SGN cell bodies and $\mathrm{Na}_{\mathrm{v}} 1.1$ on axonal processes. Dual labelling with peripherin demonstrated higher Nav1.6 and Nav1.7 expression on Type I, rather than Type II neurons. These results provide evidence for selective expression and variations in the distribution of VGSC in the rodent SGN, which may guide further studies into afferent function in the auditory pathway and therapeutic approaches for diseases such as hearing loss and tinnitus.
\end{abstract}

Keywords: Cochlea; immunohistochemistry; peripherin; RT-PCR; spiral ganglion neurons; voltage-gated sodium channels 


\section{Introduction}

There are nine recognised members of the voltage-gated sodium channel family (VGSC; $\left.\mathrm{Na}_{\mathrm{v}} 1.1-1.9\right)$. Of these $\mathrm{Na} \mathrm{a}_{\mathrm{V}} 1.1,1.2,1.3$, and 1.6 are highly (but not exclusively) expressed in the central nervous system (Westenbroek, Merrick and Catterall, 1989, Beckh et al., 1989, Whitaker et al., 2000, Whitaker et al., 2001, Tzoumaka et al., 2000) whereas Nav1.7, 1.8 and 1.9 demonstrate a more restricted expression pattern, in autonomic and sensory neurons in the peripheral nervous system (Sangameswaran et al., 1997, Toledo-Aral et al., 1997, Sangameswaran et al., 1996, Dib-Hajj et al., 1998a), and Nav1.4 and Nav1.5 represent the predominant skeletal muscle and cardiac sodium channels, respectively (Trimmer et al., 1990, Rogart et al., 1989). The Nav1.6 sub-type is also highly expressed in the peripheral nervous system where it is enriched at the nodes of Ranvier of myelinated axons and contributes to saltatory conduction (Caldwell et al., 2000, Krzemien et al., 2000).

The spontaneously active spiral ganglion neurons (SGN) form the afferent conduction pathway in the auditory periphery. There are two types of SGN, Type I neurons that innervate the inner hair cells and Type II neurons that innervate the outer hair cells (Dallos, 1992). The conduction of nerve impulses along these afferents is controlled by a number of ion channels including the voltage-gated sodium channels. Clearly, establishing the expression and distribution of the sodium channels expressed in the auditory periphery could impact our understanding of action potential dynamics and coding of auditory stimuli as well as normal and abnormal phenotypes (Patuzzi et al., 2004, Hossain et al., 2005). This knowledge would also contribute to the development of putative therapeutics for disorders such as tinnitus, enabling more precise targeting of channels involved in tinnitogenesis and, potentially provide opportunities for the rational development of sub-type selective ligands to address this area of unmet need (Vio and Holme, 2005). To date, only one study has been reported 
that has examined VGSC expression and distribution in SGN (Hossain et al., 2005) but this was limited to $\mathrm{Na}_{v} 1.2$, and $\mathrm{Na}_{\mathrm{v}} 1.6$. The aim of this study, therefore, was to fully characterise the expression and distribution pattern of relevant VGSCs using RT-PCR and Nav subtype selective antibodies in rat SGN. 


\section{Results}

\section{Nav alpha subunit expression using RT-PCR}

Validation of primer specificity in Rat cerebral cortex and DRG: To confirm the specificity of the primers used, tissue with previously documented $\mathrm{Na}_{\mathrm{V}} \alpha$ subunit expression were utilised. Distinct bands at the correct predicted sizes were observed for $\mathrm{Na}_{\mathrm{V}} 1.1, \mathrm{Na}_{\mathrm{V}} 1.2$, $\mathrm{Na}_{\mathrm{V}} 1.3$ and $\mathrm{Na}_{\mathrm{V}} 1.6$ in the cerebral cortex, with weak bands present for $\mathrm{Na}_{\mathrm{V}} 1.7$ and $\mathrm{Na}_{\mathrm{V}} 1.9$ (Fig. 1A). With the mRNA isolated from the rat DRG, distinct bands were seen for $\mathrm{Na}_{\mathrm{V}} 1.1$, $\mathrm{Na}_{v} 1.7, \mathrm{Na}_{v} 1.8$ and $\mathrm{Na}_{\mathrm{v}} 1.9$ while a weak band was observed for $\mathrm{Na}_{\mathrm{v}} 1.6$ (Fig. 1B).

Rat spiral ganglion: The RT-PCR primers specific for the $\mathrm{Na}_{\mathrm{V}} \alpha$ subunits and $\beta$-actin were used to probe the cDNA created from mRNA isolated from rat modioli homogenates. Distinct bands at the correct predicted molecular weight were observed for $\mathrm{Na}_{\mathrm{V}} 1.7, \mathrm{Na}_{\mathrm{V}} 1.6$ and $\mathrm{Na}_{\mathrm{V}} 1.1$, as well as the control gene $\beta$-actin (Fig. 1C). No bands were seen in the lane without reverse transcription, showing that there was no genomic DNA contamination.

\section{Immunocytochemical localization of $\mathrm{Na} v$ alpha subunits in spiral ganglion neurons}

$N a_{V}$ 1.7: The Nav1.7 antibody strongly labelled the cell bodies of rat SGN using fluorescently tagged secondary antibodies (Fig.2A and B). Labelling was found throughout the cytoplasm of the cell body, with no clear differentiation between membrane and cytoplasmic labelling. Variation was observed in the intensity of labelling, with some neurons strongly labelled and others only faintly labelled (Fig. 2B).

In sections of rat cochlea incubated without the primary antibody, the labelling was reduced to background levels although pale yellow puncta were noted throughout the cytoplasm (Fig. 2C). 
To demonstrate that this punctate labelling was due to non-specific fluorescence, experiments were repeated using the same $\mathrm{Na}_{\mathrm{v}} 1.7$ antibody but with streptavidin/horseradish peroxidase (HRP) and DAB to non-fluorescently visualise the primary antibody binding. Using this method, the SGN were positively labelled with brown reaction product as seen in Figs $2 \mathrm{D}$ and E. The positively labelled SGN cell bodies showed variation in staining intensity, similar in appearance to that observed in the fluorescence imaging technique. Additionally, the sections of rat cochlea incubated without the primary antibody did not show neurons labelled with the brown reaction product, nor the punctate labelling observed in the previous controls using fluorescently tagged antibodies (Fig. 2F). This confirmed that the puncta could be considered as tissue autofluorescence.

$N a_{V}$ 1.6: The Na 1.6 antibody strongly labelled the cell bodies of rat SGN (Fig. 3A and B). The pattern of distribution was similar to that seen with the Nav1.7 antibody. Labelling was found throughout the cytoplasm of the cell body, with no clear differentiation between membrane and cytoplasmic labelling. Additionally, there was again considerable variation observed in the intensity of neuronal labelling as seen in Fig. 3B. In contrast to the labelling seen with $\mathrm{Na}_{\mathrm{V}} 1.7$, peripheral and central processes were also strongly labelled for $\mathrm{Na}_{\mathrm{V}} 1.6 \alpha-$ subunits

As performed previously, sections of rat cochlea incubated without the primary antibody the labelling was reduced to background levels, although pale yellow autofluorescent puncta were observed throughout the cytoplasm as were also seen for Nav1.7 (Fig. 3C). As for Nav1.7, this punctate labelling was demonstrated as non specific by using the HRP/DAB method to visualise non-fluorescently primary antibody binding. The SGN were positively stained for $\mathrm{Na}_{\mathrm{V}} 1.6$ with the brown reaction product using this method as seen in Figs 3D and 
E. Again, positively labelled SGN cell bodies showed variation in staining intensity similar in appearance to that seen with fluorescence imaging. The distinct staining of the neuronal processes was replicated and, in addition, staining of the cell body membranes was observed (Fig. 3E). Sections of rat cochlea incubated without the primary antibody did not show neurons labelled with the brown reaction product nor the punctate labelling observed in the previous fluorescence controls (Fig. 3F).

$N a_{V} 1.1$ : The Nav1.1 antibody weakly stained the SG neurons and was only detectable using the non-fluorescent HRP/DAB method as seen in Figure 4. Weak staining was observed in the SGN cell bodies while darker staining was seen in the neuronal processes, specifically in the axons (Fig 4A and B). The sections of rat cochlea incubated without the primary antibody did not show labelled neurons (Fig. 4C).

\section{Peripherin labelling of spiral ganglion neurons}

It has been previously reported that antibodies generated against the intermediate filament protein, peripherin, preferentially label Type II SGN in sections of cochlea (Hafidi, 1998, Mou, Adamson and Davis, 1998, Reid, Flores-Otero and Davis, 2004). A small proportion $(33 / 242$ or $\approx 14 \%)$ of SGN were labelled by this antibody. Most noticeably, all the labelled neurons appeared to be smaller compared to the unlabelled neurons (Fig. 5A).

Peripherin labelling status and $N a_{V}$ l.7: The relationship between cell body area and peripherin labelling status was investigated further by dual labelling sections of cochlea with peripherin and $\mathrm{Na}_{\mathrm{v}} 1.7$ antibodies. This was performed using sections from four cochleae (Fig 5A and B). The frequency histogram of cell body area in Fig. 5C shows that distribution in peripherin positive neurons was distinctly separate from that of peripherin negative neurons. 
The mean difference in peripherin negative and positive cell body areas was significantly different, from $165.3 \mu \mathrm{m}^{2} \pm 1.8(\mathrm{n}=209)$ vs $82.2 \mu \mathrm{m}^{2} \pm 2.6(\mathrm{n}=33)$ respectively, $\mathrm{p}<0.0001$. This represents about a two-fold difference in cell body area.

On visual inspection of the sections it appeared that the peripherin positive neurons were labelled less intensely by the $\mathrm{Na}_{\mathrm{V}} 1.7$ antibody than the peripherin negative neurons. To investigate the relationship between peripherin and density of $\mathrm{Na}_{\mathrm{V}} 1.7$ labelling further, the average fluorescence intensity of the neurons labelled with the $\mathrm{Na}_{\mathrm{v}} 1.7$ antibody and peripherin negative and positive neurons was measured in four cochleae.

The mean Nav1.7 fluorescence was significantly different between the peripherin negative and positive neurons, from $120.1 \pm 1.4$ vs $100.2 \pm 3.7$ respectively at $p<0.01$. This confirmed the impression of differences in staining intensity between the two groups. Combination of these two parameters in a scatter plot of cell body area versus average fluorescence in Fig 5E, further illustrates that peripherin negative neurons possess larger cell body areas and label more strongly with Nav1.7 antibody.

Peripherin labelling status and $N a_{V}$ 1.6: An identical set of dual labelling experiments to those with $\mathrm{Na}_{\mathrm{V}} 1.7$ were performed, using peripherin and $\mathrm{Na}_{\mathrm{V}} 1.6$ antibodies and sections from the same rat cochleae that were used previously. Similar initial observations and results with regards to antibody staining, cell body area and fluorescence intensity were obtained as shown in Figs 6 A-E. With Nav1.6 the difference in distribution and means of cell body area between peripherin negative and positive was more marked than for $\mathrm{Na}_{\mathrm{V}} 1.7$. The differences in mean cell body area were significantly different with means of $185.7 \pm 2.2 \mu \mathrm{m}^{2}(\mathrm{n}=203)$ vs $74.8 \pm 3.2 \mu \mathrm{m}^{2}(\mathrm{n}=34)$ respectively, $\mathrm{p}<0.001$, or about a 2.5 fold difference in cell body area. 
Differences in mean Nav1.6 fluorescence between the negative and positive stained peripherin neurons were also significantly different, with mean difference of about 40 units; $142.6 \pm 1.7(n=203)$ vs $101.6 \pm 3.2(n=34)$ respectively, $\mathrm{p}<0.001$.

Combination of the two parameters in a scatter plot of cell body area versus average fluorescence in Fig 5E, further illustrates that peripherin negative neurons label more intensely than with $\mathrm{Na}_{\vee} 1.6$ antibody.

Comparison of $N a_{V} 1.6$ and $N a_{V} 1.7$ SGN labelling: Direct comparison of Nav1.6 and Nav1.7 immunofluorescence values was not justified as the relative antibody binding affinities were not known. However, SGN cell body area could be compared directly. The Type I means of $185.7 \pm 2.2 \mu \mathrm{m}^{2}$ vs $165.3 \mu \mathrm{m}^{2} \pm 1.8 \mu \mathrm{m}^{2}$ for $\mathrm{Na}_{\mathrm{V}} 1.6$ and $\mathrm{Na}_{\mathrm{V}} 1.7$ respectively, were highly significantly different at $\mathrm{p}<0.001$. The respective difference in Type II means, $74.8 \pm 3.2 \mu \mathrm{m}^{2}$ vs $82.2 \mu \mathrm{m}^{2} \pm 2.6$, for $\mathrm{Na}_{\mathrm{v}} 1.6$ and $\mathrm{Na}_{\mathrm{v}} 1.7$ was not significant at $\mathrm{p}>0.05$.

Peripherin labelling status and $N a_{V} 1.1$ : Dual labelling experiments with peripherin and $\mathrm{Na}_{\mathrm{V}} 1.1$ antibodies could not be performed because of the weak labelling of the SGN cell bodies using $\mathrm{Na}_{\mathrm{V}} 1.1$ antibodies. 


\section{Discussion}

Rat SGN exhibits a unique pattern of $N a_{V}$ subunit expression: The results presented here provide for the first time strong evidence that the $\alpha$-subunits, $\mathrm{Na}_{\vee} 1.7, \mathrm{Na}_{\mathrm{V}} 1.6$ and $\mathrm{Na}_{\vee} 1.1$, are selectively expressed in adult rat SGNs. There are a number of unusual features in this pattern of $\mathrm{Na}_{\mathrm{V}}$ subunit expression, as they suggest that expression in the SGN does not follow that observed in either the central or peripheral nervous system. Instead, the results presented here show $\mathrm{Na}_{\mathrm{V}}$ isoforms normally considered to be specific to the peripheral and central nervous system are both expressed in the SGN. The explanation for this may be related to the independent embryological origins of the SGN (Fekete and Wu, 2002). The peripheral and central nervous systems are known to arise from different progenitor cells in the developing embryo. The CNS forms from the dorsal ectoderm through envagination and formation of the neural tube. DRG neurons arise from neural crest cells that migrate laterally to form the peripheral ganglia (Kuan et al., 2004, Li, Say and Zhou, 2007). In contrast, the SGN develops from a distinct region of neural ectoderm known as the otic placode, which is separate from both the neural tube and neural crest cells (Holley, 2005, Fekete and $\mathrm{Wu}, 2002)$. The results from this study suggest that the otic placode displays an intermediate phenotype with regard to $\mathrm{Na}_{\mathrm{v}}$ channel expression between the CNS and PNS.

$N a_{V} 1.1$ subunit expression: $\mathrm{Na}_{\mathrm{V}} 1.1$ has been previously been shown to be strongly expressed by neurons in the central nervous system (Westenbroek, Merrick and Catterall, 1989). The preliminary results from this study appear to show that Nav1.1 is weakly expressed in the SGN with strong axonal localisation. As dual labelling experiments could not be performed using the $\mathrm{Na}_{\mathrm{V}} 1.1$ antibody, we cannot report if $\mathrm{Na}_{\mathrm{V}} 1.1$ expression is restricted to the Type I or Type II neurons. 
$N a_{V} 1.7$ subunit expression: $\mathrm{Na} \mathrm{V}_{\mathrm{V}} 1.7$ is considered to be exclusively expressed by neurons in the PNS, especially in the cell bodies (Sangameswaran et al., 1997) and peripheral terminals or growth cones (Toledo-Aral et al., 1997) of DRG neurons. The results presented here also show that the Nav1.7 subtype is expressed in the cell bodies of the rat SGN. In contrast to this rodent model, $\mathrm{Na}_{\mathrm{V}} 1.7$ was not reported to be present in the murine model of Hossain et al., (2005). This may reflect a species difference in expression of the $\mathrm{Na}_{\mathrm{V}} 1.7$ subunit.

$N a_{V}$ l.6 subunit expression: It has been previously reported that the Nav1.6 subtype is expressed in murine SGN (Hossain et al., 2005) with Nav1.6 localised at the initial segment and nodes of Ranvier and not in the cell bodies. The results here in the rat SGN are also partly in line with this earlier study. Nav1.6 labelling was found in the cell body cytoplasm as well as the processes of the rat SGN. The presence of cytoplasmic labelling in the cell body seen here is in agreement with previous reports of $\mathrm{Na}_{\mathrm{V}} 1.6$ labelling in other sensory ganglia (Tzoumaka et al., 2000, Krzemien et al., 2000, Black et al., 1999). In addition, cytoplasmic labelling has also been reported for potassium channels in the cell bodies of murine SGN (Adamson et al., 2002) and rat DRG neurons (Rasband et al., 2001). This type of labelling is most likely due to the pooling of subunit proteins in the Golgi apparatus, prior to their transport and insertion into the membrane.

Differential expression of $N a_{V} 1.6$ and $N a_{V} 1.7$ in SGN Type 1 and Type II: The measurement of SGN cell body area along with semi-quantitative fluorescence and non-fluorescence imaging techniques enabled the evident variation in labelling intensity to be explored in more detail. Resolution of differential expression was further enhanced by the use of dual labelling with peripherin antibody (Hafidi, 1998, Mou, Adamson and Davis, 1998, Reid, Flores-Otero 
and Davis, 2004). The differences in SGN Type 1 and II cell body area have been reported previously and are confirmed by this study (Berglund and Ryugo, 1987).

Whilst reduced fluorescence for both Nav1.6 and 1.7 was apparent in Type II neurons, the intensity of labelling observed was above background levels, indicating that Type II SGN express these subunits. This would support their possessing some functional capacity. Currently, little electrophysiological evidence exists to identify the specific role of Type II fibres or that they actually exhibit any acoustically driven activity (Brown, 1994, Robertson, Sellick and Patuzzi, 1999), although it has been proposed they may signal static displacement of the basilar membrane (Robertson, Sellick and Patuzzi, 1999).

The difference in cell area between $\mathrm{Na}_{\mathrm{V}} 1.6$ and 1.7 expressing Type I neurons may be explained in at least two ways. One hypothesis is that the difference may correlate with signalling function as spontaneous activity in mammalian Type I afferents is known to range between 0-120 spikes $\sec ^{-1}$, which correlates with axon diameter (Liberman, 1982). It would be reasonable to assume that axon diameter also correlates with cell body area and that the expression of Nav1.6 and 1.7 in Type I SGN may then be related to the spontaneous and/or driven activity of Type I fibres. Alternatively, the differences may simply reflect more intense membranous staining by $\mathrm{Na}_{\mathrm{V}} 1.6$ over 1.7 . $\mathrm{Na}_{\mathrm{V}} 1.6$ has a role in action potential initiation and propagation in many neurons due to its localisation at the axon hillock and nodes of Ranvier, respectively. By contrast $\mathrm{Na}_{\mathrm{v}} 1.7$, a channel that shows slow inactivation and stays open in response to slow ramp depolarisations, may have a role in initiating action potential initiation at the hair cell-afferent fibre synapse. 
Expression of other $N a_{V}$ isoforms in the SGN: The expression of other voltage-gated sodium channel isoforms was also investigated in this study. RT-PCR failed to show the expression of mRNA for $\mathrm{Na}_{\vee} 1.2, \mathrm{Na}_{\vee} 1.3, \mathrm{Na}_{\vee} 1.8$ and $\mathrm{Na}_{\vee} 1.9$, indicating that these isoforms are not expressed in the rat SGN.

Interestingly, in the murine study by Hossain et al., (2005), $\mathrm{Na}_{\mathrm{V}} 1.2$ expression in the in the Organ of Corti was observed, but only in the efferent innervation to inner and outer hair cells (Hossain et al., 2005). The absence of evidence for expression of $\mathrm{Na}_{\mathrm{V}} 1.8$ and Nav1.9 isoforms in this study is in line with earlier observations that TTX completely abolished inward sodium current in isolated SGN (Santos-Sacchi, 1993). Nav1.4 and Nav1.5 expression in the SGN was not studied, as these isoforms are believed to be selectively expressed in skeletal and cardiac muscle respectively (Catterall, Goldin and Waxman, 2005).

Control results: The extensive analysis and comprehensive documentation of the expression of Nav subunits in the CNS and PNS neurons provided positive controls for RT-PCR primers used in the current study. CNS neurons have been shown to express $\mathrm{Na}_{\mathrm{v}} 1.1, \mathrm{Na}_{\mathrm{v}} 1.2$ (Westenbroek, Merrick and Catterall, 1989), Nav1.3 (Beckh et al., 1989) and Nav1.6 (Tzoumaka et al., 2000), and mRNA isolated from the cerebral cortex was used to test the specificity of the RT-PCR primers designed for these $\mathrm{Na}_{\mathrm{V}}$ subunits. $\mathrm{Na}_{\mathrm{V}} 1.7$ and $\mathrm{Na}_{\vee} 1.9$ were also weakly identified by the RT-PCR primers. While these proteins have not been identified in the cerebral cortex, the mRNA has been detected in this tissue previously (Dib-Hajj et al., 1998a, Belcher et al., 1995). The mRNA isolated from the DRG was used as a positive control to validate the specificity of the RT-PCR primers designed to detect $\mathrm{Na}_{V} 1.7, \mathrm{Na}_{\mathrm{V}} 1.8$ and $\mathrm{Na}_{\mathrm{v}} 1.9$, as the DRG has been previously reported to express these subunits (Sangameswaran et al., 1997, Dib-Hajj et al., 1998a, Dib-Hajj et al., 1998b). The RT-PCR 
primers also identified Nav1.1 mRNA in the DRG tissues. This result has been reported previously (Beckh, 1990), but whilst the mRNA for Nav1.1 has been identified in the DRG, the protein has not been detected in the peripheral nervous system (Gordon et al., 1987). Both these control tissues yielded results that confirmed that the designed primers were specific for their respective $\mathrm{Na}_{\mathrm{V}}$ isoforms.

Antibody specificity is necessary for the reliable interpretation of immunohistochemical data. Sections of rat cochlea without primary antibodies did not display fluorescence specific to the binding of the secondary antibodies to their antigens. However, non-specific cytoplasmic yellow puncta were observed in the SG cell bodies. These results indicate that in the adult rat SGN there are other sources of endogenous fluorescence, possibly lipofuscin. This has also been reported in other adult neural ganglia, including the retina, vestibular and dorsal root ganglion and cerebellar Purkinje cells (Sans, Bartolami and Fraysse, 1996, Samorajski, Ordy and Rady-Reimer, 1968). Furthermore, we are confident that these puncta were due to nonspecific fluorescence, since we used non-fluorescence DAB/HRP visualisation methods to validate the original results.

Characterising $\mathrm{Na}_{V}$ Isoforms in the Auditory pathway- Therapeutic Applications: The characterisation of $\mathrm{Na}_{\mathrm{V}}$ isoforms in the periphery of the normal auditory pathway contribute to the development of therapeutics for treating conditions such as tinnitus. The clinical evidence that voltage-gated sodium blockers may have a role in ameliorating certain types of tinnitus is well documented because lignocaine, a use-dependent sodium channel blocker and local anaesthetic, is the gold standard tinnitolytic agent and is effective in around $50 \%$ of patients (Baguley et al., 2005). Following ototrauma, it is apparent that marked plastic changes occur in the auditory pathway some of which have parallels with sensory nerve 
trauma (Moller, 1997, Kaltenbach et al., 1998). In models of neuropathic pain this is accompanied by changes in pattern and expression of $\mathrm{Na}_{\mathrm{V}}$ subtype and profound changes in neuronal excitability (Devor, 2006, Novakovic et al., 1998, Black et al., 2004, Cummins and Waxman, 1997). Several $\mathrm{Na}_{\vee}$ channel subtypes including $\mathrm{Na}_{\vee} 1.7$ and $\mathrm{Na}_{\vee} 1.8$ have been implied to regulate spontaneous firing in damaged nociceptive afferents although there is much debate from studies using antisense knock-down methodologies and transgenic animals as to which are the most important (for reviews see Krafte and Bannon, 2008, Momin and Wood, 2008).

The use of appropriate models of ototrauma would establish whether similar or other changes in $\mathrm{Na}_{\mathrm{v}}$ isoforms may underlie tinnitus. This would provide the basis for optimal matching of tinnitolytic therapeutics to their tinnitogenic target. 


\section{Experimental Methods}

\section{RT-PCR}

Tissue extraction: Male Wistar rats $(250-400 \mathrm{~g})$ were sacrificed using Euthanal ${ }^{\circledR}$ (IP) in accordance with UK Home Office Animals Act 1986 (schedule 1). The dorsal root ganglia (DRG) and cerebral cortex were rapidly excised and frozen over dry ice in a sterile RNase/DNase free tube. The temporal bones were removed and excess bone was removed to leave the bony inner ear segment that contained the cochlea. The otic capsule of the cochlea was removed to reveal the modiolus, which was then carefully removed from the remaining bone and frozen over dry ice as above.

$m R N A$ isolation and cDNA synthesis: Two modioli- from the left and right ear of one animalsix DRGs and $35 \mathrm{mg}$ of cerebral cortex were used per analysis. The tissues were homogenised separately in lysis buffer, by pestle and mortar, and centrifuged in a QIAshredder (QIAGEN, Crawley, UK). The total RNA was isolated from the homogenates using the RNeasy mini kit (QIAGEN). The RNA was eluted in RNase free water and the remaining DNA was removed by using DNase I (Invitrogen, Paisley, UK). The total RNA was reverse transcribed to complementary (c)DNA using SuperScript ${ }^{\mathrm{TM}}$ III Reverse Transcriptase (Invitrogen) The cDNA was stored at $-80^{\circ} \mathrm{C}$ until use.

PCR reaction: The PCR reaction was performed using BIOTAQ DNA polymerase (Bioline, London, UK), custom designed sense and antisense primers at $0.5 \mu \mathrm{M}$ final concentration (Sigma Genosys, Cambridge, UK) and $1 \mu \mathrm{l}$ of cDNA using a T-Gradient Biometra thermocycler (Biotron, Göttingen, Germany). Thirty-five PCR cycles were performed using annealing temperatures between 54 and $59^{\circ} \mathrm{C}$. The PCR products were separated by electrophoresis on a $1 \%$ agarose gel with ethidium bromide and a 100 base pair DNA ladder (Promega, Southampton, UK) at 110V. The gel was photographed under ultraviolet 
illumination using a digital camera and Kodak digital science 1D software (Kodak). The mRNA isolation, cDNA synthesis and PCR reaction was repeated four times, using modioli from a fresh rat each time.

Primer design: Primer pairs specific to the $\mathrm{Na}_{\mathrm{V}}$ alpha subunits and $\beta$-actin used are summarised in table 1. The primer pairs were designed to cross intron-exon boundaries as determined from the rat sequences. This would show any genomic DNA contamination of the PCR products as a higher base pair size band than the calculated band. The identity of PCR products was confirmed by sequencing.

\section{Tissue preparation for immunohistochemistry}

Dorsal root ganglion extraction: Male Wistar rats (250-300g) were sacrificed by stunning and cervical dislocation, in accordance with UK Home Office Animals Act 1986 (Schedule 1). The DRG were rapidly excised, embedded in Tissue-Tek OCT (Sakura Finetek, Bayer plc, Newbury, UK), frozen over dry ice/hexane and stored at $-20^{\circ} \mathrm{C}$. Frozen sections were cut $(10 \mu \mathrm{m})$ from tissue blocks, mounted on Polysine ${ }^{\mathrm{TM}}$ slides (VWR International, Lutterworth, UK) and air-dried. Tissue sections were fixed in freshly prepared $2 \%$ paraformaldehyde solution for 10 minutes at room temperature and washed (1x15 mins) in phosphate buffered saline (PBS, pH 7.4).

Cochlea extraction: Male Wistar rats $(250-300 \mathrm{~g})$ were sacrificed using Euthanal ${ }^{\circledR}$ (IP) in accordance with UK Home Office Animals Act 1986 (schedule 1). The circulatory system of the animal was flushed transcardially with warm PBS supplemented with heparin. For fixation the animal was perfused transcardially with warm $2 \%$ paraformaldehyde solution. The temporal bones were dissected and excess bone was removed to leave the bony inner ear segment that contained the cochlea. The cochleae were placed in $2 \%$ paraformaldehyde 
solution for 30 minutes and demineralised in $8 \%$ EDTA until soft (4 to 10 days at $4^{\circ} \mathrm{C}$ ). They were then placed in PBS with $30 \%$ sucrose overnight at $4^{\circ} \mathrm{C}$ and then were infiltrated with Tissue Tek OCT overnight at $4^{\circ} \mathrm{C}$ (Cho et al., 2004). The fixed cochleae were quickly frozen in Tissue Tek over dry ice/hexane and stored at $-20^{\circ} \mathrm{C}$. Frozen $10 \mu \mathrm{m}$ sections were cut from tissue blocks, mounted on Polysine ${ }^{\mathrm{TM}}$ slides and air dried. Tissue sections were washed $(1 \mathrm{x} 15$ mins) in PBS.

\section{Immunohistochemistry on frozen sections}

Antibody information: Information about the primary and secondary antibodies used in this study is presented in table 2.

Fluorescent probe staining: For detection of sodium channel subtypes, the slides were incubated in the following: (1) Blocking solution of PBS containing 10\% goat serum, supplemented with $0.5 \%$ Triton X-100 for $30 \mathrm{~min}$ at room temperature; (2) Sodium channel subtype specific primary polyclonal antibodies raised in rabbit (see table 2 for details) diluted in blocking solution and incubated overnight at $4^{\circ} \mathrm{C}$; (3) Goat anti-rabbit IgG conjugated with fluorescein isothiocyanate (FITC) for 2 hours at room temperature. Between each incubation step, the sections were thoroughly washed with PBS. Sections were mounted with Citifluor AF1 mountant (UKC Chem. Lab, Kent, UK).

Control experiments were carried out to determine the amount of non-specific binding by omitting the primary antiserum from the incubation media. Pre-incubation of primary antibody with the blocking peptide overnight reduced the labelling to background levels. 
For identification of Type II SG neurons, experiments were carried out using an antiperipherin monoclonal antibody MAB 1527 raised in mouse (Millipore, Watford, UK) as this protein is known to be selectively expressed in Type II SG neurons (Hafidi, 1998, Mou, Adamson and Davis, 1998, Reid, Flores-Otero and Davis, 2004). Immunostaining was visualised with goat anti-mouse secondary antibodies conjugated with Texas Red (Jackson ImmunoResearch).

The sections were viewed using a Nikon Labophot 2A microscope equipped for epifluorescense imaging and photography, with a monochromatic CCD camera, frame grabber card and software (Scion Image ${ }^{\mathrm{TM}}$ ). Photography of tissue sections was carried out with the appropriate filters for FITC or Texas Red.

Scion Image $^{\mathrm{TM}}$ (Scion Corporation, Frederick, Maryland USA) was used to measure the cell body area and average fluorescence of the neurons from the epifluorescent images. Only neurons that showed an unlabelled nucleus and an intact cell body were measured. The fluorescence scale ranged from: $0=$ black; $255=$ white. Unless otherwise stated, this scale is used throughout the results and discussion sections.

Non-fluorescence DAB/HRP staining: For non-fluorescence detection of sodium channel subtypes, the tissue sections were incubated sequentially in the following solutions: (1) $0.2 \%$ Hydrogen peroxide in methanol for 15 minutes; (2) $10 \%$ swine serum and $0.5 \%$ Triton X-100 in PBS for 30 minutes at room temperature; (3) Anti-rabbit polyclonal antibodies as described above, overnight at $4^{\circ} \mathrm{C}$; (5) Swine anti-rabbit biotin conjugated $\mathrm{IgG}$, diluted with $10 \%$ swine serum in PBS for 35 minutes at room temperature (DAKO, Ely, UK); (6) Streptavidin-Horseradish peroxidase (HRP) conjugate prediluted for 30 minutes at room 
temperature (DAKO); (7) 3, 3'-diaminobenzidine solution (DAB substrate kit, DAKO) for 4 minutes at room temperature; (8) $70 \%$ IMS for 5 minutes followed by $100 \%$ IMS for 5 minutes and $100 \%$ xylene twice for 5 minutes. Between steps 1 and 8 the tissue sections were thoroughly washed with PBS. Sections were mounted using DPX (RA Lamb, Eastbourne, UK).

The slides were examined using a light microscope equipped with a digital camera (Moticam 2300, GT Vision, Haverhill, Suffolk, UK) and images were captured using Motic Images Plus 2.0

\section{Statistical Analysis}

Statistical analysis was carried out with data entered into a Microsoft Office Excel 2007 spreadsheet. Comparison of different data groups was performed using the two-tailed Students t-test. Results are expressed as means \pm se and a $\mathrm{p}=0.05$ significance level was adopted throughout. 


\section{Acknowledgements}

AF was in receipt of BBSRC CASE studentship in association with GlaxoSmithKline and a grant from the Ménière's Society. The authors would like to thank Mrs Susan- Giblett for providing valuable help in the HRP/DAB staining and Dr Amit Prasai for conducting the preliminary experiments in this study. 


\begin{tabular}{|c|c|c|c|c|}
\hline Subunit & Forward primer & Reverse primer & $\begin{array}{l}\text { Predicted } \\
\text { band } \\
\text { (bp) }\end{array}$ & $\begin{array}{c}\text { Annealing } \\
\text { temperature } \\
\left({ }^{\circ} \mathrm{C}\right)\end{array}$ \\
\hline $\mathrm{Na}_{v} 1.1$ & GCGTGCTGCCGGGAAAACATAC & ACGTCCTTCGCTCGCCCTCTGA & 576 & 59 \\
\hline $\mathrm{Na}_{\vee} 1.2$ & CGTCCGCAGAATCCAGAGA & CTTGAAGGGTCTTCCAACAAGTC & 705 & 58 \\
\hline $\mathrm{Na}_{\vee} 1.3$ & AGGGAAGGATTGACTTGCC & TGGACCTCTCCTTAGAGTCCA & 295 & 58 \\
\hline $\mathrm{Na}_{\vee} 1.6$ & AAGTGGACAGCCTACGGC & TTGTTGACAATATCGATTTCGAACCG & 364 & 58 \\
\hline $\mathrm{Na}_{\vee} 1.7$ & GACGACAGCGGCACGACTAAT & AGCTGCGAAGATCCCTGTAAAGA & 402 & 54 \\
\hline $\mathrm{Na}_{\vee} 1.8$ & GATCCGTGGAACTGGCTGGA & GAGGAATGCCCACGCAAAGGAATC & 482 & 58 \\
\hline $\mathrm{Na}_{\vee} 1.9$ & CCCTGCTGCGCTCGGTGAAGAA & GACAAAGTAGATCCCAGAGG & 395 & 58 \\
\hline$\beta$-actin & TACAACCTCCTTGCAGCTCC & GGATCTTCATGAGGTAGTCTGTC & 630 & 59 \\
\hline
\end{tabular}

Table 1. PCR Primers. Primers were either designed or modified from others previously published. $\mathrm{Na}_{\mathrm{V}} 1.2, \mathrm{Na}_{\mathrm{V}} 1.3, \mathrm{Na}_{\mathrm{V}} 1.6$ (Wooltorton et al., 2007); $\mathrm{Na}_{\mathrm{V}} 1.8$ (Dib-Hajj et al., 1998b); Na 1.9 (Dib-Hajj et al., 1998a); $\beta$ - actin (Raff et al., 1997).

\begin{tabular}{|c|c|c|c|c|}
\hline Antibody & Host & Dilution & Supplier & Product code \\
\hline Anti Nav1.1 & Rabbit & $1: 200$ & Alomone Labs & ASC-001 \\
\hline Anti-Nav1.6 & Rabbit & $1: 200$ & Alomone Labs & ASC-009 \\
\hline Anti-Nav1.7 & Rabbit & $1: 200$ & Alomone Labs & ASC-008 \\
\hline Anti-Peripherin & Mouse & $1: 100$ & Millipore & MAB1527 \\
\hline Anti-rabbit/FITC & Goat & $1: 400$ & Jackson ImmunoResearch & $111-095-144$ \\
\hline Anti-mouse/Texas red & Goat & $1: 400$ & Jackson ImmunoResearch & $115-075-146$ \\
\hline Anti-rabbit/biotin & Swine & $1: 350$ & DAKO & E0353 \\
\hline
\end{tabular}

Table 2. Immunohistochemistry antibodies. Details of the antibodies used in the study. Entries with / indicates a conjugation, i.e. anti-rabbit/biotin means anti-rabbit conjugated with biotin. 


\section{References}

Adamson, C. L., Reid, M.A., Mo, Z., Bowne English, J. \& Davis, R.L. (2002) Firing features and potassium channel content of murine spiral ganglion neurons vary with cochlear location. The Journal of Comparative Neurology, 447, 331-350.

Baguley, D. M., Jones, S., Wilkins, I., Axon, P.R. \& Moffat, D.A. (2005) The inhibitory effect of intravenous lidocaine infusion on tinnitus after translabyrinthine removal of vestibular schwannoma: A double blind, placebo-controlled, crossover study. Otology \& Neurotology, 26, $169-176$.

Beckh, S. (1990) Differential expression of sodium channel mRNAs in rat peripheral nervous system and innervated tissues. FEBS Lett., 262, 317 322.

Beckh, S., Noda, M., Lubbert, H. \& Numa, S. (1989) Differential regulation of three sodium channel messenger RNAs in the rat central nervous system during development. EMBO J., 8, $3611-3616$.

Belcher, S. M., Zerillo, C.A., Levenson, R., Ritchie, J.M. \& Howe, J.R. (1995) Cloning of a sodium channel alpha subunit from rabbit schwann cells. Proc. Natl. Acad. Sci. U. S. A., 92, 1103411038.

Berglund, A. M. \& Ryuge, D.K. (1987) Hair cell innervation by spiral ganglion neurons in the mouse. J. Comp. Neurol., 255, $560-570$.

Black, J. A., Liu, S., Tanaka, M., Cummins, T.R. \& Waxman, S.G. (2004) Changes in the expression of tetrodotoxin-sensitive sodium channels within dorsal root ganglia neurons in inflammatory pain. Pain, 108, 237247.

Black, J. A., Cummins, T.R., Plumpton, C., Chen, Y.H., Hormuzdiar, W., Clare, J.J. \& Waxman, S.G. (1999) Upregulation of a silent sodium channel after peripheral, but not eentral, nerve injury in DRG neurens. J. Neurophysiol., 82, 2776-2785.

Brown, M. C. (1994) Antidromic responses of single units from the spiral ganglion. J. Neurophysiol., 71, 1835-1847.

Caldwell, J. H., Schaller, K.L., Lasher, R.S., Peles, E. \& Levinson, S.R. (2000) Sodium ehannel Na 1.6 is localized at nodes of ranvier, dendrites, and synapses. PNAS, 97, 56165620 .

Catterall, W. A., Goldin, A.L. \& Waxman, S.G. (2005) International union of pharmacology. XLVII. nomenclature and structure function relationships of voltage gated sodium channels. Pharmacel. Rev., 57, 397-409.

Chø, Y., Gong, T.L., Kanicki, A., Altschuler, R.A. \& Lomax, M.I. (2004) Noise overstimulation induces immediate early genes in the rat cochlea. Molecular Brain Research, 130, 134-148. 
Cummins, T. R. \& Waxman, S.G. (1997) Downregulation of tetrodotoxin-resistant sodium eurrents and upregulation of a rapidly repriming tetrodotoxin-sensitive sodium current in small spinal sensory neurons after nerve injury. Journal of Neuroscience, 17, 3503-3514.

Dallos, P. (1992) The active cochlea. The journal of neuroscience, 12, 4575-4585.

Devor, M. (2006) Sodium channels and mechanisms of neuropathic pain. Jomrnal of Pain, 7, S3-S12.

Dib-Hajj, S. D., Black, J.A., Cummins, T.R., Kenney, A.M., Kocsis, J.D. \& Waxman, S.G. (1998a) Rescue of alpha SNS sodium channel expression in small dorsal root ganglion neurons after axotomy by nerve growth factor in vivo. J. Neurophysiol., 79, 26682676.

Dib-Hajj, S. D., Tyrrell, L., Black, J.A. \& Waxman, S.G. (1998b) NaN, a novel voltage gated na channel, is expressed preferentially in peripheral sensory neurons and down-regulated after axotomy. Proc. Natl. Acad. Sci. U. S. A., 95, $8963-8968$.

Fekete, D. M. \& Wu, D.K. (2002) Revisiting cell fate specification in the inner ear. Curr. Opin. Neurobiol., 12, 35-42.

Gordon, D., Merrick, D., Auld, V., Dunn, R., Goldin, A.L., Davidson, N. \& Catterall, W.A. (1987) Tissue-specific expression of the RI and RII sodium channel subtypes. Proc. Natl. Acad. Sei. U.S. A., 84, 8682-8686.

Hafidi, A. (1998) Peripherin like immunoreactivity in type II spiral ganglion cell body and projections. Brain Res., 805, 181-190.

Holley, M. C. (2005) Keynote review: The auditory system, hearing loss and potential targets for drug development. Drug Discov. Today, 10, 1269-1282.

Hossain, W. A., Antic, S.D., Yang, Y., Rasband, M.N. \& Morest, D.K. (2005) Where is the spike generator of the cochlear nerve? voltage gated sodium channels in the mouse cochlea. Journal of Neuroscience, 25, 68576868 .

Kaltenbach, J. A., Godfrey, D.A., Neumann, J.B., MeCaslin, D.L., Afman, C.E. \& Zhang, J. (1998) Changes in spontaneous neural activity in the dorsal cochlear nucleus following exposure to intense sound: Relation to threshold shift. Hear. Res., 124, $78-84$.

Krzemien, D. M., Sehaller, K.L., Levinsen, S.R. \& Caldwell, J.H. (2000) Immunolocalization of sodium channel isøform $\mathrm{NaCh} 6$ in the nervous system. J. Comp. Neurol., 420, $70-83$.

Kuan, C. Y., Tannahill, D., Cook, G.M. \& Keynes, R.J. (2004) Somite polarity and segmentat patterning of the peripheral nervous system. Mech. Dev., 121, 1055-1068.

Li, H. Y., Say, E.H. \& Zhou, X.F. (2007) Isolation and characterization of neural crest progenitors from adult dorsal root ganglia. Stem Cells, 25, $2053-2065$.

Liberman, M. C. (1982) Single-neuron labeling in the cat auditory nerve. Science, 216, 1239 1241. 
Moller, A. R. (1997) Similarities between chronic pain and timnitus. The American Journal of Otology, 18, 577585.

Mou, K., Adamson, C.L. \& Davis, R.L. (1998) Time-dependence and cell-type specificity of synergistic neurotrophin actions on spiral ganglion neurons. J. Comp. Neurel., 402, 129-139.

Novakovic, S. D., Tzoumaka, E., MeGivern, J.G., Haraguchi, M., Sangameswaran, L., Gogas, K.R., Eglen, R.M. \& Hunter, J.C. (1998) Distribution of the tetrodotoxin resistant sodium channel PN3 in rat sensory neurons in normal and neuropathic conditions. Journal of Neuroscience, 18, 2174-2187.

Patuzzi, R. B., Brown, D.J., McMahon, C.M. \& Halliday, A.F. (2004) Determinants of the spectrum of the neural electrical activity at the round window: Transmitter release and neurat depolarisation. Hear. Res., 190, 87108.

Raff, T., van der Giet, M., Endemann, D., Wiederholt, T. \& Paul, M. (1997) Design and testing of beta actin primers for RT PCR that do not co amplify processed pseudogenes. Biotechniques, 23, 456-460.

Rasband, M. N., Park, E.W., Vanderah, T.W., Lai, J., Porreca, F. \& Trimmer, J.S. (2001) Distinct potassium channels on pain-sensing neurons. Proc. Natl. Acad. Sci. U. S. A., 98, 1337313378.

Reid, M. A., Flores-Otero, J. \& Davis, R.L. (2004) Firing patterns of type II spiral ganglion neurons in vitro. Journal of Neuroscience, 24, $733-742$.

Robertson, D., Sellick, P.M. \& Patuzzi, R. (1999) The continuing search for outer hair cell afferents in the guinea pig spiral ganglion. Hear. Res., 136, 151-158.

Rogart, R. B., Cribbs, L.L., Muglia, L.K., Kephart, D.D. \& Kaiser, M.W. (1989) Molecular eloning of a putative tetrodotoxin resistant rat heart na+ channel isoform. Proc. Natl. Acad. Sci. U. S. A. ; Proceedings of the National Academy of Sciences of the United States of America, 86, 8170-8174.

Samorajski, T., Ordy, J.M. \& Rady Reimer, P. (1968) Lipofuscin pigment aceumulation in the nervous system of aging mice. Anat. Rec., 160, 555-573.

Sangameswaran, L., Fish, L.M., Koch, B.D., Rabert, D.K., Delgado, S.G., Inicka, M., Jakeman, L.B., Novakovic, S., Wong, K., Sze, P., Tzoumaka, E., Stewart, G.R., Herman, R.C., Chan, H., Eglen, R.M. \& Hunter, J.C. (1997) A novel tetrodotoxin sensitive, voltagegated sodium channel expressed in rat and human dorsal root ganglia. J. Biol. Chem., 272, 14805-14809.

Sangameswaran, L., Delgado, S.G., Fish, L.M., Koch, B.D., Jakeman, L.B., Stewart, G.R., Sze, P., Hunter, J.C., Eglen, R.M. \& Herman, R.C. (1996) Structure and function of a novel voltage gated, tetrodotoxin-resistant sodium channel specific to sensory neurons. J. Biol. Chem., 271, 5953-5956.

Sans, A., Bartolami, S. \& Fraysse, B. (1996) Histopathology of the peripheral vestibular system in small vestibular schwannomas. Am. J. Otol., 17, 326-324. 
Santos Sacchi, J. (1993) Voltage-dependent ionic conductances of type I spiral ganglion cells from the guinea pig inner ear. Journal of Neuroscience, 13, 3599 3611.

Foledo-Aral, J. J., Moss, B.L., He, Z.J., Koszowski, A.G., Whisenand, T., Levinson, S.R., Wolf, J.J., Silos-Santiago, I., Halegeua, S. \& Mandel, G. (1997) Identification of PN1, a predominant voltage - dependent sodium channel expressed principally in peripheral neurons. Proc. Natl. Acad. Sci. U. S. A., 94, 15271532.

Trimmer, J. S., Cooperman, S.S., Agnew, W.S. \& Mandel, G. (1990) Regulation of muscle sodium channel transeripts during development and in response to denervation. Dev. Biol., 142, $360-367$.

Tzoumaka, E., Tischler, A.C., Sangameswaran, L., Eglen, R.M., Hunter, J.C. \& Novakovic, S.D. (2000) Differential distribution of the tetrodotoxin-sensitive rPN4/NaCh6/Sen8a sodium channel in the nervous system. J. Neurosci. Res., 60, 37-44.

Vio, M. M. \& Holme, R.H. (2005) Hearing loss and tinnitus: 250 million people and a US\$10 billion potential market. Drug Discov. Today, 10, 1263-1265.

Westenbroek, R. E., Merrick, D.K. \& Catterall, W.A. (1989) Differential subcellular localization of the RI and RII nat channel subtypes in central neurons. Neuron, 3, 695704.

Whitaker, W. R., Clare, J.J., Powell, A.J., Chen, Y.H., Faull, R.L. \& Emson, P.C. (2000) Distribution of voltage gated sodium channel alpha-subunit and beta-subunit mRNAs in human hippocampal formation, cortex, and cerebellum. J. Comp. Neurol., 422, 123-139.

Whitaker, W. R. J., Faull, R.L.M., Waldvogel, H.J., Plumpton, C.J., Emsen, P.C. \& Clare, J.J. (2001) Comparative distribution of voltage-gated sodium channel proteins in human brain. Mol. Brain Res., 88, 3753.

Wooltorton, J. R., Gaboyard, S., Hurley, K.M., Price, S.D., Garcia, J.L., Zhong, M., Lysakowski, A.\& Eatock, R.A. (2007) Developmental changes in two voltage dependent sodium currents in utricular hair cells. J. Neurophysiol., 97, 1684-1704.

Adamson CL, Reid MA, Mo Z, Bowne-English J, Davis RL (2002) Firing features and potassium channel content of murine spiral ganglion neurons vary with cochlear location. The Journal of Comparative Neurology 447:331-350.

Baguley DM, Jones S, Wilkins I, Axon PR, Moffat DA (2005) The inhibitory effect of intravenous lidocaine infusion on tinnitus after translabyrinthine removal of vestibular schwannoma: A double-blind, placebo-controlled, crossover study. Otology \& Neurotology 26:169-176. 
Beckh S, Noda M, Lubbert H, Numa S (1989) Differential regulation of three sodium channel messenger RNAs in the rat central nervous system during development. EMBO J 8:3611$\underline{3616 .}$

$\underline{\text { Beckh S (1990) Differential expression of sodium channel mRNAs in rat peripheral nervous }}$ system and innervated tissues. FEBS Lett 262:317-322.

Belcher SM, Zerillo CA, Levenson R, Ritchie JM, Howe JR (1995) Cloning of a sodium channel alpha subunit from rabbit schwann cells. Proc Natl Acad Sci U S A 92:11034-11038.

Berglund AM, Ryugo DK (1987) Hair cell innervation by spiral ganglion neurons in the mouse. J Comp Neurol 255:560-570.

Black JA, Cummins TR, Plumpton C, Chen YH, Hormuzdiar W, Clare JJ, Waxman SG (1999) Upregulation of a silent sodium channel after peripheral, but not central, nerve injury in DRG neurons. J Neurophysiol 82:2776-2785.

Black JA, Liu S, Tanaka M, Cummins TR, Waxman SG (2004) Changes in the expression of tetrodotoxin-sensitive sodium channels within dorsal root ganglia neurons in inflammatory pain. Pain 108:237-247.

Brown MC (1994) Antidromic responses of single units from the spiral ganglion. J Neurophysiol 71:1835-1847.

Caldwell JH, Schaller KL, Lasher RS, Peles E, Levinson SR (2000) Sodium channel Nav․․․ is localized at nodes of ranvier, dendrites, and synapses. PNAS 97:5616-5620. 
Catterall WA, Goldin AL, Waxman SG (2005) International union of pharmacology. XLVII. nomenclature and structure-function relationships of voltage-gated sodium channels. Pharmacol Rev 57:397-409.

Cho Y, Gong TL, Kanicki A, Altschuler RA, Lomax MI (2004) Noise overstimulation induces immediate early genes in the rat cochlea. Molecular Brain Research 130:134-148.

Cummins TR, Waxman SG (1997) Downregulation of tetrodotoxin-resistant sodium currents and upregulation of a rapidly repriming tetrodotoxin-sensitive sodium current in small spinal sensory neurons after nerve injury. Journal of Neuroscience 17:3503-3514.

Dallos P (1992) The active cochlea. The Journal of Neuroscience 12:4575-4585.

Devor M (2006) Sodium channels and mechanisms of neuropathic pain. Journal of Pain 7:S3$\underline{\text { S12. }}$

Dib-Hajj SD, Tyrrell L, Black JA, Waxman SG (1998a) NaN, a novel voltage-gated na channel, is expressed preferentially in peripheral sensory neurons and down-regulated after axotomy. Proc Natl Acad Sci U S A 95:8963-8968.

Dib-Hajj SD, Black JA, Cummins TR, Kenney AM, Kocsis JD, Waxman SG (1998b) Rescue of alpha-SNS sodium channel expression in small dorsal root ganglion neurons after axotomy by nerve growth factor in vivo. J Neurophysiol 79:2668-2676.

Fekete DM, Wu DK (2002) Revisiting cell fate specification in the inner ear. Curr Opin Neurobiol 12:35-42. 
Gordon D, Merrick D, Auld V, Dunn R, Goldin AL, Davidson N, Catterall WA (1987)

Tissue-specific expression of the RI and RII sodium channel subtypes. Proc Natl Acad Sci U

S A 84:8682-8686.

Hafidi A (1998) Peripherin-like immunoreactivity in type II spiral ganglion cell body and projections. Brain Res 805:181-190.

Holley MC (2005) Keynote review: The auditory system, hearing loss and potential targets for drug development. Drug Discov Today 10:1269-1282.

Hossain WA, Antic SD, Yang Y, Rasband MN, Morest DK (2005) Where is the spike generator of the cochlear nerve? voltage-gated sodium channels in the mouse cochlea. Journal of Neuroscience 25:6857-6868.

$\underline{\text { Kaltenbach JA, Godfrey DA, Neumann JB, McCaslin DL, Afman CE, Zhang J (1998) }}$ Changes in spontaneous neural activity in the dorsal cochlear nucleus following exposure to intense sound: Relation to threshold shift. Hear Res 124:78-84.

$\underline{\text { Krafte DS, Bannon AW (2008) Sodium channels and nociception: Recent concepts and }}$ therapeutic opportunities. Current Opinion in Pharmacology 8:50-56.

$\underline{\text { Krzemien DM, Schaller KL, Levinson SR, Caldwell JH (2000) Immunolocalization of }}$ sodium channel isoform NaCh6 in the nervous system. J Comp Neurol 420:70-83.

$\underline{\text { Kuan CY, Tannahill D, Cook GM, Keynes RJ (2004) Somite polarity and segmental }}$ patterning of the peripheral nervous system. Mech Dev 121:1055-1068.

$\underline{\text { Li HY, Say EH, Zhou XF (2007) Isolation and characterization of neural crest progenitors }}$ from adult dorsal root ganglia. Stem Cells 25:2053-2065. 
Liberman MC (1982) Single-neuron labeling in the cat auditory nerve. Science 216:12391241.

Moller AR (1997) Similarities between chronic pain and tinnitus. The American Journal of Otology 18:577-585.

Momin A, Wood JN (2008) Sensory neuron voltage-gated sodium channels as analgesic drug targets. Curr Opin Neurobiol 18:383-388.

Mou K, Adamson CL, Davis RL (1998) Time-dependence and cell-type specificity of synergistic neurotrophin actions on spiral ganglion neurons. J Comp Neurol 402:129-139.

Novakovic SD, Tzoumaka E, McGivern JG, Haraguchi M, Sangameswaran L, Gogas KR, Eglen RM, Hunter JC (1998) Distribution of the tetrodotoxin-resistant sodium channel PN3 in rat sensory neurons in normal and neuropathic conditions. Journal of Neuroscience 18:2174-2187.

Patuzzi RB, Brown DJ, McMahon CM, Halliday AF (2004) Determinants of the spectrum of the neural electrical activity at the round window: Transmitter release and neural depolarisation. Hear Res 190:87-108.

$\underline{\text { Raff T, van der Giet M, Endemann D, Wiederholt T, Paul M (1997) Design and testing of }}$ beta-actin primers for RT-PCR that do not co-amplify processed pseudogenes. Biotechniques 23:456-460.

$\underline{\text { Rasband MN, Park EW, Vanderah TW, Lai J, Porreca F, Trimmer JS (2001) Distinct }}$ potassium channels on pain-sensing neurons. Proc Natl Acad Sci U S A 98:13373-13378. 
Reid MA, Flores-Otero J, Davis RL (2004) Firing patterns of type II spiral ganglion neurons in vitro. Journal of Neuroscience 24:733-742.

$\underline{\text { Robertson D, Sellick PM, Patuzzi R (1999) The continuing search for outer hair cell afferents }}$ in the guinea pig spiral ganglion. Hear Res 136:151-158.

$\underline{\text { Rogart RB, Cribbs LL, Muglia LK, Kephart DD, Kaiser MW (1989) Molecular cloning of a }}$ putative tetrodotoxin-resistant rat heart na+ channel isoform. Proc Natl Acad Sci U S A ; Proceedings of the National Academy of Sciences of the United States of America 86:8170$\underline{8174 .}$

Samorajski T, Ordy JM, Rady-Reimer P (1968) Lipofuscin pigment accumulation in the nervous system of aging mice. Anat Rec 160:555-573.

$\underline{\text { Sangameswaran L, Delgado SG, Fish LM, Koch BD, Jakeman LB, Stewart GR, Sze P, }}$ Hunter JC, Eglen RM, Herman RC (1996) Structure and function of a novel voltage-gated, tetrodotoxin-resistant sodium channel specific to sensory neurons. J Biol Chem 271:59535956.

Sangameswaran L, Fish LM, Koch BD, Rabert DK, Delgado SG, Ilnicka M, Jakeman LB, Novakovic S, Wong K, Sze P, Tzoumaka E, Stewart GR, Herman RC, Chan H, Eglen RM, Hunter JC (1997) A novel tetrodotoxin-sensitive, voltage-gated sodium channel expressed in rat and human dorsal root ganglia. J Biol Chem 272:14805-14809.

$\underline{\text { Sans A, Bartolami S, Fraysse B (1996) Histopathology of the peripheral vestibular system in }}$ small vestibular schwannomas. Am J Otol 17:326-324.

Santos-Sacchi J (1993) Voltage-dependent ionic conductances of type I spiral ganglion cells from the guinea pig inner ear. Journal of Neuroscience 13:3599-3611. 
Toledo-Aral JJ, Moss BL, He ZJ, Koszowski AG, Whisenand T, Levinson SR, Wolf JJ, $\underline{\text { Silos-Santiago I, Halegoua S, Mandel G (1997) Identification of PN1, a predominant voltage- }}$ dependent sodium channel expressed principally in peripheral neurons. Proc Natl Acad Sci U S A 94:1527-1532.

Trimmer JS, Cooperman SS, Agnew WS, Mandel G (1990) Regulation of muscle sodium channel transcripts during development and in response to denervation. Dev Biol 142:360$\underline{367 .}$

Tzoumaka E, Tischler AC, Sangameswaran L, Eglen RM, Hunter JC, Novakovic SD (2000) Differential distribution of the tetrodotoxin-sensitive $\mathrm{rPN} 4 / \mathrm{NaCh} 6 / \mathrm{Scn} 8$ a sodium channel in the nervous system. J Neurosci Res 60:37-44.

Vio MM, Holme RH (2005) Hearing loss and tinnitus: 250 million people and a US\$10 billion potential market. Drug Discov Today 10:1263-1265.

Westenbroek RE, Merrick DK, Catterall WA (1989) Differential subcellular localization of the RI and RII na+ channel subtypes in central neurons. Neuron 3:695-704.

Whitaker WR, Clare JJ, Powell AJ, Chen YH, Faull RL, Emson PC (2000) Distribution of voltage-gated sodium channel alpha-subunit and beta-subunit mRNAs in human hippocampal formation, cortex, and cerebellum. J Comp Neurol 422:123-139.

Whitaker WRJ, Faull RLM, Waldvogel HJ, Plumpton CJ, Emson PC, Clare JJ (2001) Comparative distribution of voltage-gated sodium channel proteins in human brain. Mol Brain Res 88:37-53. 
Wooltorton JR, Gaboyard S, Hurley KM, Price SD, Garcia JL, Zhong M, Lysakowski A, Eatock RA (2007) Developmental changes in two voltage-dependent sodium currents in utricular hair cells. J Neurophysiol 97:1684-1704. 
A

$\begin{array}{ll}\beta \text {-actin } & \mathrm{Na}_{\mathrm{v}} 1.1 \\ \mathrm{M}+- & +-\end{array}$
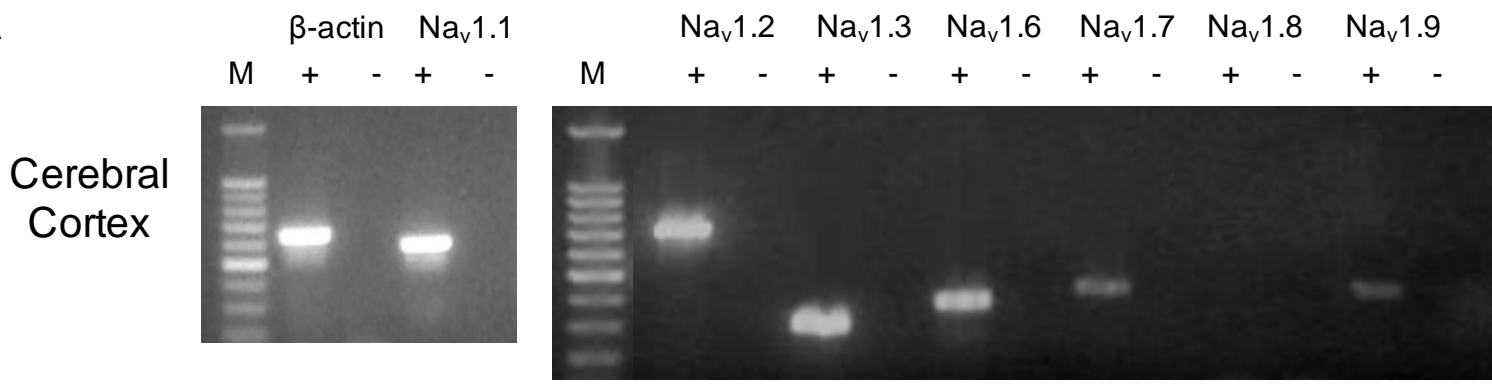

\section{B \\ Dorsal \\ Root \\ Ganglion}
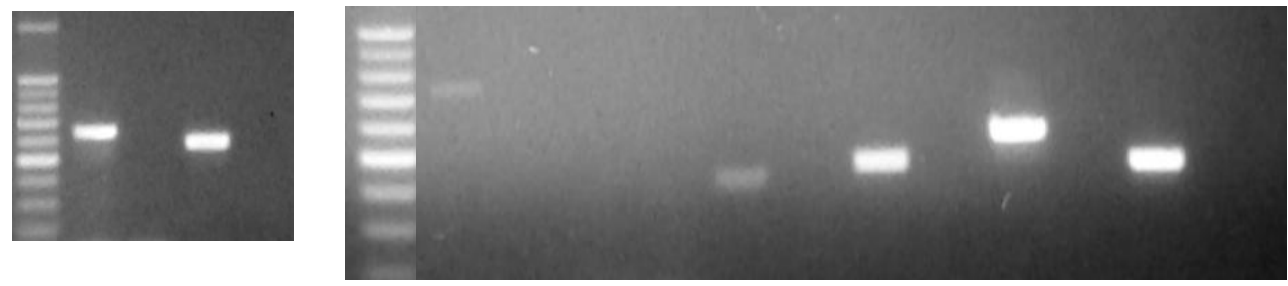

\section{Spiral \\ Ganglion \\ Neurons}
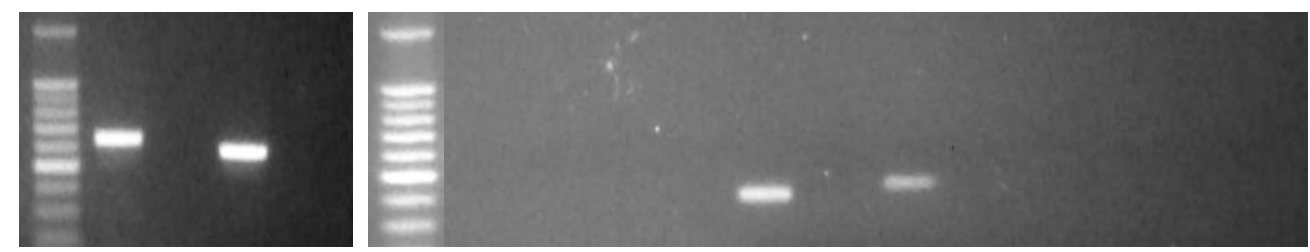

Figure 1. $\mathrm{Na}_{v}$ mRNA channel expression in adult rat nervous tissues. PCR products were separated by electrophoresis on a 1\% agarose gel stained with ethidium bromide. (A) PCR products were detected for Nav1.1, 1.2, 1.3 and 1.6 in the rat cerebral cortex, with weak bands for $\mathrm{Na}_{v} 1.7$ and $\mathrm{Na}_{v} 1.9$. (B) PCR products were detected for Nav1.1, 1.6, 1.7, 1.8 and 1.9 in the rat DRG. (C) PCR products were detected for Nav1.1, 1.6 and 1.7 in the rat SGN. Al tissues were positive for $\beta$-actin. M lane, 100bp ladder with brightest band representing 500bp. Expected product sizes are given in methods section. PCR was performed either in the presence (+) or absence $(-)$ of reverse transcription. 

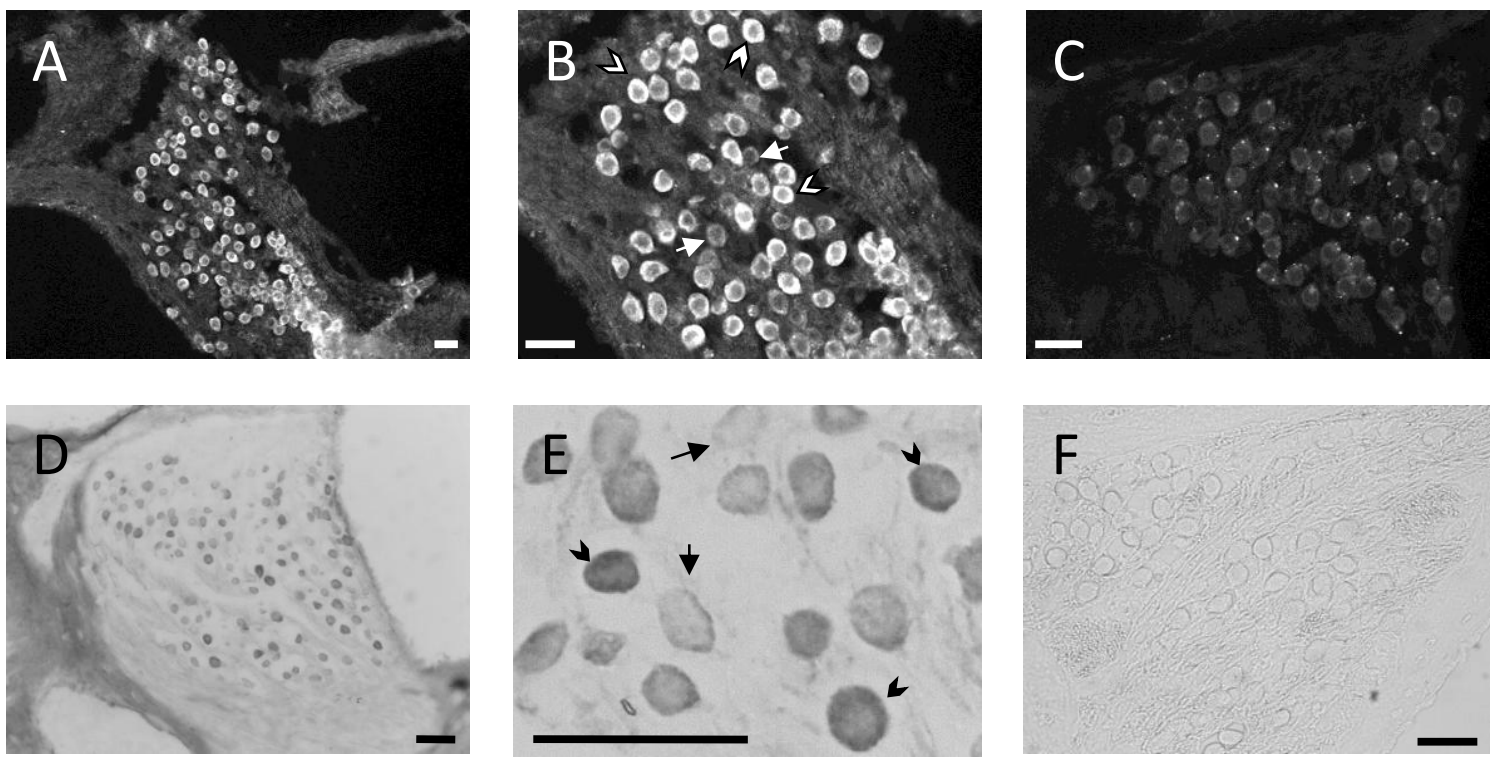

Figure 2. Distribution of $\mathrm{Na}_{v} \mathbf{1 . 7}$ in rat SGN. Micrographs showing $\mathrm{Na}_{v} 1.7$ labell ing in the rat $\mathrm{SGN}$ using fluorescent $(A, B)$ and non-fluorescent $(D, E)$. Both techniques show positive labelling of the neurons although someappear to be less intensely stained (arrow) than others (arrowhead).(C) Micrograph showing rat SGN incubated without the primary antibody. (F) Phase contrast micrograph of HRP-DAB labelled SGN incubated without the primaryantibody

Scale bars $=30 \mu \mathrm{m}$ for all images 

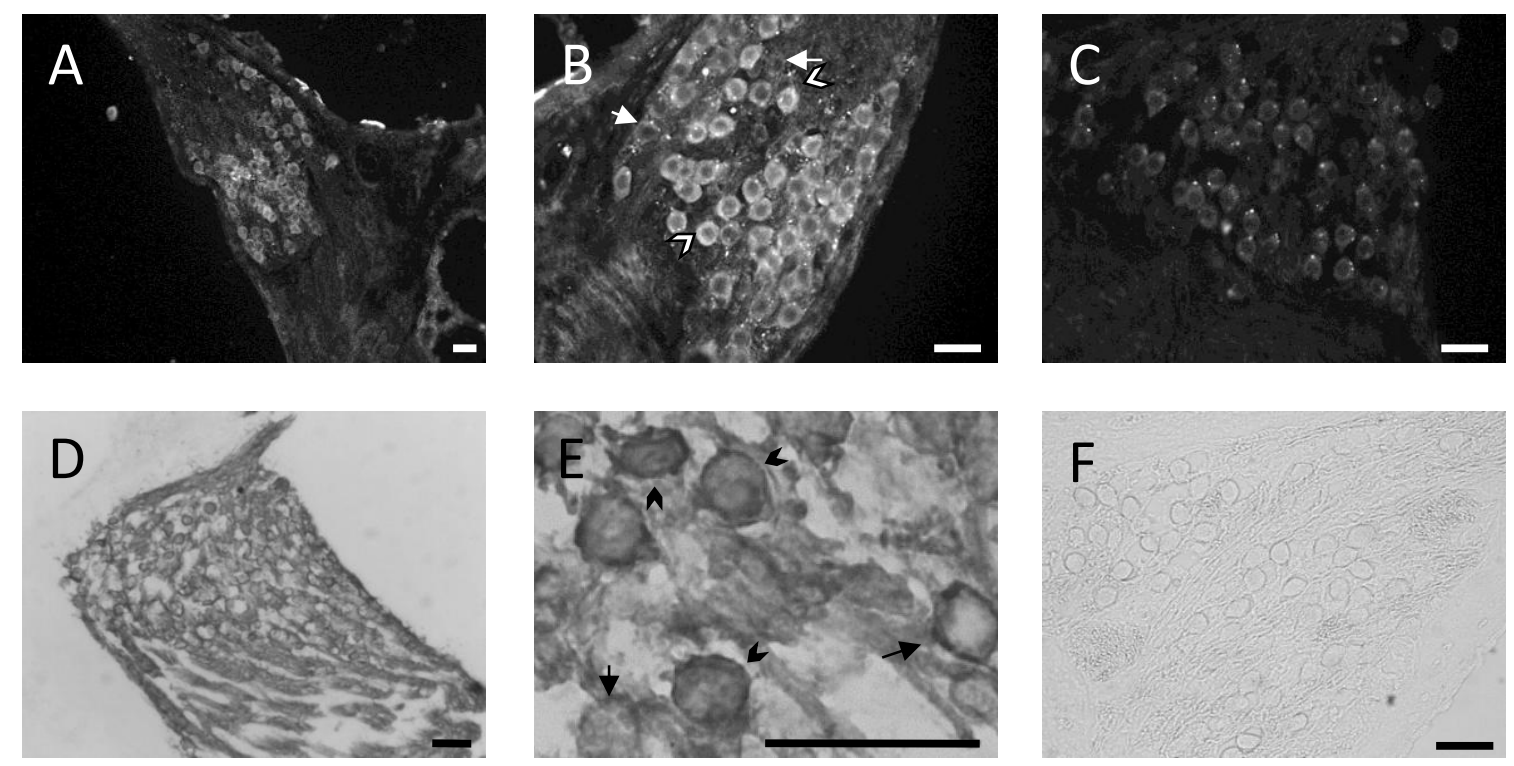

Figure 3. Distribution of $\mathrm{Na}_{y} 1.6$ in rat SGN. Micrographs showing Na 1 .6 labell ing in the rat SGN using fluorescent $(A, B)$ and non-fluorescent $(D, E)$ immunocytochemistry. Both techniques show positive labelling of the neurons although some appear to be less intensely stained (arrow) than others (arrowhead). (C)Micrograph showing rat SGN incubated without the primary antibody. (F) Phase contrast micrograph of HRP-DAB labelled SGN incubated without the primary antibody.

Scale bars $=30 \mu \mathrm{m}$ for all images. 

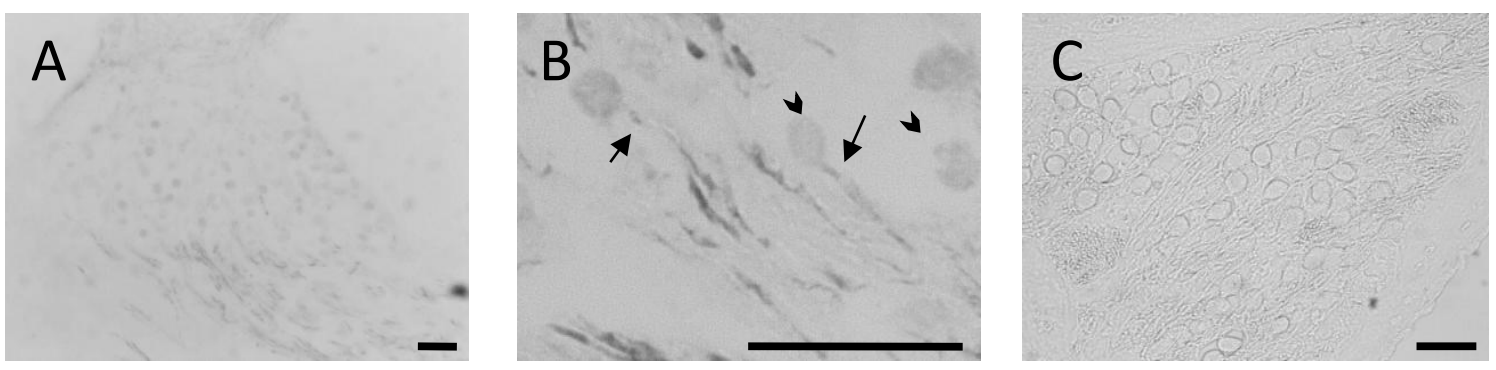

Figure 4. Distribution of $\mathrm{Na}_{\mathrm{v}} 1.1$ in rat SGN. Micrographs showing Nav1.1 labell ing in the rat $\mathrm{SGN}$ using non-fluorescent (A,B) immunocytochemistry. (A,B) Faint labell ing of the SGN cell bodies was observed (arrowhead) while the axons were more intensely labelled (arrow). (C) Phase contrast micrograph showing rat SGNincubated without the primary antibody.

Scale bars $=30 \mu \mathrm{m}$ for allimages. 

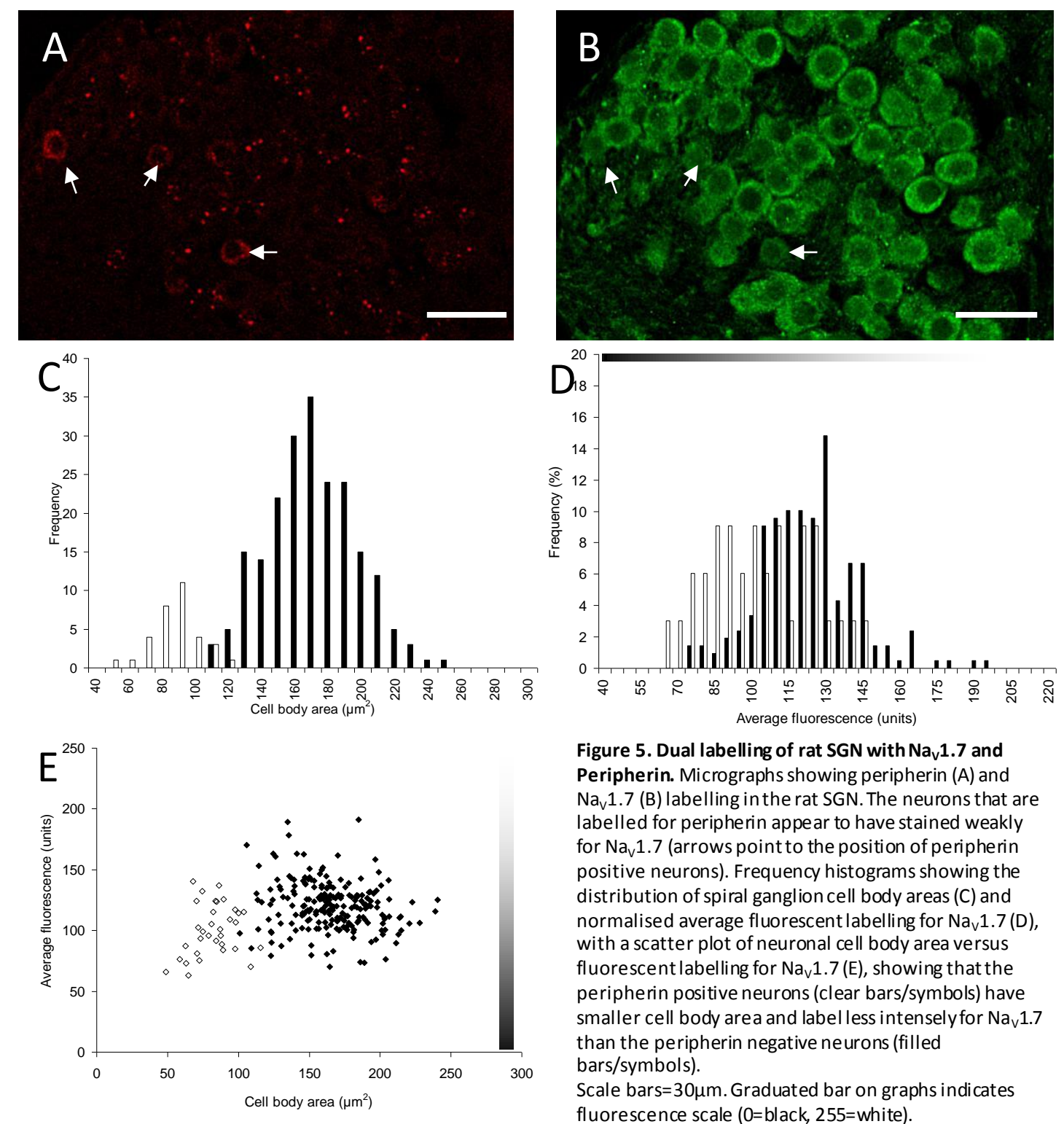

Figure 5. Dual labelling of rat SGN with $\mathrm{Na}_{\mathrm{v}} \mathrm{1.7}$ and Peripherin. Micrographs showing peripherin $(A)$ and $\mathrm{Na}_{\mathrm{v}} 1.7$ (B) labelling in the rat SGN. The neurons that are labelled for peripherin appear to have stained weakly for $\mathrm{Na}_{\mathrm{v}} \mathrm{1} .7$ (arrows point to the position of peripherin positive neurons). Frequency histograms showing the distribution of spiral ganglion cell body areas (C) and normalised average fluorescent labelling for $\mathrm{Na}_{v} 1.7$ (D), with a scatter plot of neuronal cell body area versus fluorescent labelling for $\mathrm{Na}_{\mathrm{V}} 1.7(\mathrm{E})$, showing that the peripherin positive neurons (clear bars/symbols) have smaller cell body area and labelless intensely for $\mathrm{Na}_{v} 1.7$ than the peripherin negative neurons (filled bars/symbols).

Scale bars $=30 \mu \mathrm{m}$. Graduated bar on graphs indicates fluorescence scale ( $0=$ black, 255=white). 

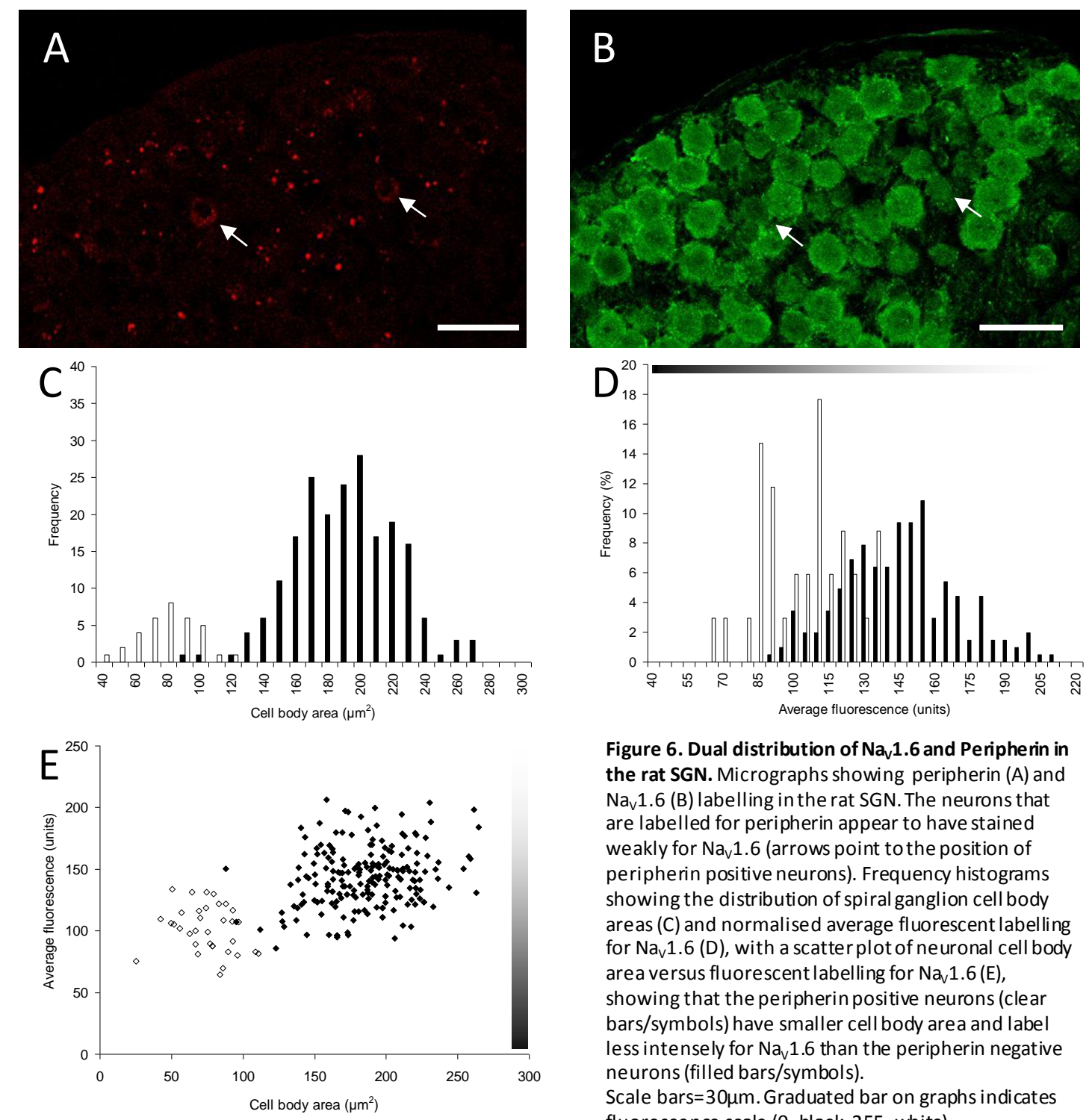

Figure 6. Dual distribution of $\mathrm{Na}_{\mathrm{v}} \mathrm{1} .6$ and Peripherin in the rat SGN. Micrographs showing peripherin (A) and $\mathrm{Na}_{\mathrm{V}} 1.6$ (B) labell ing in the rat SGN. The neurons that are labelled for peripherin appear to have stained weakly for $\mathrm{Na}_{\mathrm{v}} 1.6$ (arrows point to the position of peripherin positive neurons). Frequency histograms showing the distribution of spiral ganglion cell body areas (C) and normalised average fluorescent labelling for $\mathrm{Na}_{\mathrm{v}} 1.6$ (D), with a scatter plot of neuronal cell body area versus fluorescent labelling for $\mathrm{Na}_{\sqrt{ }} 1.6(\mathrm{E})$, showing that the peripherin positive neurons (clear bars/symbols) have smaller cell body area and label less intensely for $\mathrm{Na}_{\mathrm{v}} \mathrm{1} .6$ than the peripherin negative neurons (filled bars/symbols).

Scale bars $=30 \mu \mathrm{m}$. Graduated bar on graphs indicates fluorescence scale (0=black, 255=white). 